\title{
KEBIJ AKAN FORMULASI KETENTUAN PIDANA DALAM DELIK KESUSILAAN (PERZINAHAN) YANG BERBASIS NILAI KEADILAN RELIGIUS
}

\author{
Adiansyah Nurahman*, Eko Soponyono \\ Program Studi Magister Ilmu Hukum, Fakultas Hukum, Universitas Diponegoro \\ adiansyah.nurahman@gmail.com
}

\begin{abstract}
The first principle shows that Indonesia is a country that recognizes the existence of God, therefore, as a religious state, the rules of criminal provisions must not conflict with religious and legal values that live in society. This study discusses the criminal provisions of the decency offense (adultery) in force today which has been based on the value of religious justice and the policy of formulating criminal justice religious provisions. The study used a normative juridical method with qualitative analysis. The result of this research, that the criminal provisions in the decency offense currently in effect have not been based on the value of religious justice. The policy of formulating criminal provisions with religious justice in adultery offenses is carried out by extending the meaning of zina in the criminal provisions by referring to the holy book (Al-Quran).
\end{abstract}

Keywords: Criminal J ustice; Morality; Religious J ustice.

\begin{abstract}
ABSTRAK
Sila pertama menunjukan bahwa Indonesia adalah negara yang mengakui adanya Tuhan, oleh sebab itu, sebagai negara yang religius, maka aturan ketentuan pidana tidak boleh bertentangan dengan nilai-nilai agama dan hukum yang hidup di masyarakat. Penelitian ini membahas ketentuan pidana dalam delik kesusilaan (perzinahan) yang berlaku saat ini telah berbasis nilai keadilan religius dan kebijakan formulasi ketentuan pidana yang berkeadilan religius. Penelitian menggunakan metode yuridis normatif dengan analisa kualitatif,. Hasil penelitian bahwa ketentuan pidana dalam delik kesusilaan yang berlaku saat ini belum berlandaskan nilai keadilan religius. Kebijakan formulasi ketentuan pidana yang berkeadilan religius dalam delik perzinahan dilakukan dengan mempeluas makna zina yang ada dalam ketentuan pidana dengan merujuk pada kitab suci (Al-Quran).
\end{abstract}

Kata Kunci: Ketentuan Pidana; Kesusilaan; Keadilan Religius.

\footnotetext{
* Corresponding Author
} 


\section{A. PENDAHULUAN}

Keadilan merupakah salah satu tujuan hukum yang paling banyak dibicarakan. Dalam ajaran Islam, keadilan adalah ketetapan Allah bagi kosmos atau alam raya ciptaannnya. Keadilan adalah prinsip yang merupakan hukum seluruh hajat raya. Oleh karenanya melanggar keadilan adalah melanggar hukum kosmos dan dosa ketidakadilan akan mempunyai dampak kehancuran tatanan masyarakat manusia (Amin, 2014).

Indonesia adalah Negara berdasarkan Pancasila dan UUD 1945. Segala peraturan perundang-undangan yang berlaku di negeri ini tidak boleh bertentangan dengan Pancasila dan UUD 1945. Pancasila merupakan falsafah dan dasar dari Negara Kesatuan Republik Indonesia. Penjabaran dari nilai-nilai Pancasila yaitu adanya peraturan Undang-undang yang lebih rinci dalam mengaturnya, akan tetapi peraturan perundangundangan terutama ketentuan pidana tidak boleh bertentangan dengan nilai-nilai yang ada dalam Pancasila. Pancasila adalah pandangan hidup bangsa Indonesia yang sila pertama yaitu berKetuhanan Maha Esa yang artinya bahwa manusia adalah makhluk ciptaan Tuhan yang wajib percaya dan menyembahnya (Yudhanti, 2016).

Idealnya, hukum suatu negara harus sesuai dengan nilai-nilai budaya dan mencerminkan kepribadian masyarakatnya (Ali, 2016). Formulasi ketentuan pidana yang berkeadilan religius harus mampu menggali nilai-nilai ajaran dari Tuhan dan nilai-nilai yang hidup di masyarakat. Indonesia merupakan negara yang terdiri dari beberapa pulau dengan segala kekayaan keanekaragamannya baik adat istiadat dan budaya, maka setiap daerah di Indonesia tentu memiliki nilai-nilai dan falsafah dalam menjalani kehidupan sehari-hari. Para Legislator dalam merumuskan suatu aturan pidana harus mampu menggali nilai-nilai yang hidup di masyarakat agar dapat terwujud keadilan bagi seluruh rakyat Indonesia. Formulasi hukum pidana yang berkeadilan religius tetap harus mensinkronisasikan antara nilai-nilai agama dan nilai yang telah hidup di masyarakat dengan ketentuan pada sistem hukum nasional, mengingat banyak nilai-nilai yang hidup di masyarakat bersumber dari nilai-nilai religius berdasarkan Ketuhanan, sehingga kelak tidak terjadi benturan yang membuat rakyat merasa tidak mendapat keadilan.

Formulasi keadilan yang religius tidak bisa dilepaskan dari Kitab Suci. Indonesia yang merupakan negara Pancasila yang mengakui adanya Ketuhanan Yang Maha Esa dalam sila pertama. Kata "adil" berarti menetapkan hukum dengan benar. Jadi seorang yang adil adalah berjalan lurus dan sikapnya selalu menggunakan ukuran yang sama, bukan ukuran ganda. Persamaan itulah yang merupakan makna asal kata adil, yang menjadikan pelakunya tidak berpihak kepada salah seseorang yang berselisih, 
dan pada dasarnya pula seseorang yang adil "berpihak kepada yang benar" karena baik yang benar maupun yang salah sama-sama harus memperoleh haknya (Soponyono, 2017). Untuk menentukan formulasi hukum itu adil atau tidak harus memiliki ukuran, agar tidak ada masyarakat yang merasa didiskriminasi terhadap aturan formulasi pidana yang dikeluarkan oleh lembaga perumus Undang-undang.

Adil saat menetapkan hukum dalam AlQuran berbunyi "Sesungguhnya Allah menyuruh kamu menyampaikan amanat kepada yang berhak menerimanya, dan (menyuruh kamu) apabila menetapkan hukum diantara manusia supaya kamu menetapkan dengan adil" (Q.S An-Nisaa' ayat 58). Adil dalam firman di atas bermakna memberikan sanksi-sanksi dan pidana sesuai dengan yang telah disyariatkan oleh Allah melalui rosulnya. Banyak sekali perintah Allah dalam Al-Quran yang menyerukan kepada hambanya agar berlaku adil.

Munculnya perkara kesusilaan yang semakin marak di Indonesia menuntut sebuah pemahaman yang sangat mendalam tentang tatanan nilai yang pantas dan berlaku dalam sebuah masyarakat yang dikenal dengan norma kesusilaan. Demi terwujudnya keadilan yang religius, maka penegakan hukum terhadap tindak pidana kesusilaan harus dilakukan kajian yang mendalam, para penegak hukum tidak hanya melihat aturan yang berlaku semata, akan tetapi harus melihat nilai-nilai hukum yang hidup di masyarakat serta nilai-nilai religius yang berpedoman pada kitab suci. Sila pertama Pancasila menyatakan "Ketuhanan Yang Maha Esa", dengan demikian aturan ketentuan pidana terkait kesusilaan harus berlandaskan nilai-nilai ketuhanan untuk menghasilkan keadilan yang religius.

Secara umum tindak pidana kesusilaan diartikan sebagai tindak pidana yang berhubungan dengan masalah kesusilaan (etika). Hal ini menunjukan bahwa menentukan batasan atau pengertian mengenai kesusilaan tidaklah sederhana (Lumingkewas, 2016)

Saat ini, aturan ketentuan pidana terkait delik kesusilaan terutama perzinahan masih dianggap belum mampu memberikan keadilan bagi masyarakat. Ketentuan pidana masih belum berlandaskan nilai keadilan religius, yang mana masih dianggap menciderai hukum yang berlaku di masyarakat (hukum agama dan hukum yang hidup). Banyak nilai-nilai dalam delik kesusilaan ternyata bertentangan dengan nilai-nilai masyarakat yang sangat religi, hal tersebut disebabkan karena KUHP yang merupakan peninggalan kolonial memiliki jiwa yang berbeda dengan jiwa bangsa Indonesia, hal ini jika dipaksakan akan berbenturan dengan nilai dan kepentingan baru yang tidak mustahil justru akan menimbulkan kejahatan baru. Masalah delik perzinahan merupakan salah satu contoh aktuall adanya benturan antara pengertian dan paham tentang zina dalam KUHP dengan kepentingan/nilai sosial masyarakat. Adanya 
Law Reform

Volume 15, Nomor 1, Tahun 2019
Program Studi Magister IImu Hukum

Fakultas Hukum Universitas Diponegoro benturan tersebut justru menjadikan hukum tidak menghasilkan kemanfaatan dan keadilan yang melindungi masyarakat.

Barda Nawawi Arief (Arief, 1994) mengatakan adanya kesenjangan / ketidaksesuaian (gap/discrepency) dan bahkan perbedaan nilai/kepentingan inilah yang tidak mustahil menjadi faktor timbulnya ketidakpuasan dalam praktek penegakan hukum. Bahkan dapat pula menjadi faktor penyebab timbulnya korban (faktor victimogen) maupun timbulnya delik/kejahatan lain (faktor criminogen). Berdasarkan hasil penelitian, Latief Wiyata (Christianto, 2016) menunjukan bahwa gangguan terhadap istri penyebab utama dilakukannya carok dengan prosentase perkara dari tahun 1990 sebanya 21 perkara $(67,7 \%)$, tahun 1991 sebanyak 23 perkara (71,9\%), tahun 1992 sebanyak 26 perkara (72,2\%), tahun 1993 sebanyak 28 perkara (50,9\%) dan tahun 1994 sebanyak 27 perkara $(50,9 \%)$.

Carok adalah budaya Madura yang masih dipertahankan, Carok merupakan tradisi bertarung yang disebabkan karena alasan tertentu yang berhubungan dengan harga diri kemudian diikuti antar kelompok dengan menggunakan senjata (biasanya celurit). Hal itu juga disebabkan karena ketentuan pidana yang berlaku di Indonesia belum mampu memberikan keadilan. Formulasi Ketentuan pidana yang religius diharapkan mampu menjadi solusi ditengah susahnya keadilan yang didapat oleh masyarakat. Meningat, sejak awal pendiri bangsa menekankan bahwa negara ini didirikan untuk mewujudkan bangsa Indonesia yang sejahtera. Pengertian negara kesehjateraan yang dianut di Indonesia menuntut adanya materiil maupun spritual (Soemarsono, 2007). Penggalian nilai-nilai religius berdasarkan tuntunan Tuhan adalah hal yang harus dilakukan dalam rangka pembangunan hukum nasional yang berlandaskan Pancasila, sebagaimana yang disampaikan Prof. Moeljatno bahwa, "dalam negara kita yang berdasarkan Pancasila, dengan adanya sila Ketuhanannya, maka tiap ilmu pengetahuan (termasuk ilmu hukum, pen.) yang tidak dibarengi dengan ilmu ketuhanan adalah tidak lengkap". Notohamidjojo pun sering menegaskan, bahwa "tanggung jawab jurist ialah merohaniahkan hukum", dan "penilaian scienta yuridis harus mendalam dan mendasar pada conscientia" (nilai kebenaran, keadilan, kejujuran, kasih sayang antar sesama dsb). Dengan demikian tidak ada "sekulerisasi" dalam pendidikan hukum dan ilmu hukum di Indonesia (Arief, 2015).

Ilmu hukum yang tidak dibarengi dengan ilmu Ketuhanan tidak lengkap mengandung makna bahwa para pembuat Undang-undang dan penegak hukum maupun mahasiswa hukum harus melihat hukum berdasarkan ilmu ketuhanan, dengan demikian harus dilakukan penggalian nilai-nilai yang ada dalam rumusan pasal dalam ketentuan pidana apakah telah telah mengandung ilmu Ketuhanan atau belum. Penggalian nilai-nilai 
Ketuhanan akan menambah ilmu pengetahuan sehingga dalam menjalankan hukum dapat terwujud keadilan yang religius.

Beberapa penelitian sebelumnya tentang tindak pidana kesusilaan, Fredi Yuniantoro, (2017) membahas eksploitasi seksual sebagai sentuk sejahatan sesusilaan salam Peraturan PerundangUndangan. Kejahatan Kesusilaan dan Pelecehan Seksual Ditinjau dari Kebijakan Hukum Pidana (Zainal, 2017) dan Perlindungan Hak Bagi Tersangka Dalam Kasus Tindak Pidana Kesusilaan. (Ayu, \& Suparwi, 2018). Penelitian Alyssa Miller (2018) yang membahas penghukuman terhadakan delik kesusilaan (perzinahan) melalui studi komparatif Hukum Perzinaan di Amerika Serikat dan Taiwan dan Dampaknya pada Perempuan.

Pembahasan tentang prinsip-prinsip hukum yang dapat dijadikan dasar justifikasi untuk mengkriminalisasi perilaku perzinahan di India (Sekhri, A. 2014). Kejahatan delik kesusilaan diteliti dalam studi komparatif antara Hukum Pidana Indonesia dan Hukum Pidana Islam dan ancaman sanksinya (Fajar, \& Busthami, 2018). Penelitian ini lebih terfokus membahas ketentuan pidana dalam delik kesusilaan (perzinahan) yang berlaku saat ini apakah telah berbasis nilai keadilan religius dan kebijakan formulasi ketentuan pidana yang berkeadilan religius.

Tujuan dari penelitian ini untuk mengetahui apakah ketentuan pidana dalam delik kesusilaan terutama perzinahan yang berlaku sekarang telah mengandung nilai keadilan religius atau belum. Kemudian untuk mengetahui formulasi ketentuan pidana yang berbasis nilai keadilan religius.

\section{B. METODE PENELITIAN}

Penelitian ini merupakan jenis penelitian yuridis normatif (legal research) dan dikategrikan enelitian hukum normatif/doktrinal atau Sering sekali dalam penelitian ini hukum dikonsepkan sebagai apa yang tertulis dalam peraturan perundang-undangan (law in books) atau hukum dikonsepkan sebagai kaidah atau norma yang merupakan patokan berprilaku manusia yang dianggap pantas. Bahkan hukum dan metode pengumpulan datanya adalah dengan studi kepustakaan/studi dokumen. Pendekatan yang digunakan dalam penelitian ini adalah pendekatan perundang-undangan serta pendekatan perundangundangan serta pendekatan analisis konsep.

\section{HASIL DAN PEMBAHASAN}

\section{Ketentuan Pidana dalam Delik Kesusilaan (Perzinahan) Yang Berlaku Saat Ini}

Istilah ketentuan pidana merupakan istilah umum untuk menyebut keseluruhan aturan/norma hukum pidana. L.H.C Hulsman pernah mengemukakan, bahwa sistem pemidanaan (the sentencing system) adalah "aturan perundangundangan yang berhubungan dengan sanksi 
pidana dan pemidanaan (the statutory rules relating to penal sanctions and punisment) (Areif, 2012).

Munculnya perkara kesusilaan yang semakin marak di Indonesia menuntut sebuah pemahaman yang sangat mendalam tentang tatanan nilai yang pantas dan berlaku dalam sebuah masyarakat yang dikenal dengan norma kesusilaan. Demi terwujudnya keadilan yang religius, maka penegakan hukum terhadap tindak pidana kesusilaan harus dilakukan kajian yang mendalam, para penegak hukum tidak hanya melihat aturan yang berlaku semata, akan tetapi harus melihat nilai-nilai hukum yang hidup di masyarakat serta nilai-nilai religius yang berpedoman pada kitab suci. Sila pertama Pancasila menyatakan "Ketuhanan Yang Maha Esa", dengan demikian aturan ketentuan pidana terkait kesusilaan harus berlandaskan nilai-nilai ketuhanan untuk menghasilkan keadilan yang religius.

Secara singkat dapat dikatakan bahwa delik kesusilaan adalah delik yang berhubungan dengan (masalah kesusilaan). Definisi singkat dan sederhana itu apabila dikaji lebih lanjut untuk mengetahui seberapa jauh ruang lingkupnya ternyata tidaklah mudah, karena pengertian dan batas-batas "kesusilaan" itu cukup luas dan dapat berbeda-beda menurut pandangan dan nilai-nilai yang berlaku di dalam masyarakat. Terlebih pada dasarnya setiap delik atau tindak pidana mengandung di dalamnya pelanggaran terhadap nilai-nilai kesusilaan; bahkan dikatakan bahwa hukum itu sendiri pada hakikatnya merupakan nilainilai kesusilaan yang minimal (das Recht ist das ethische Minimum) (Arief, 2011).

Hukum yang berbasis nilai keadilan religius seharusnya tidak hanya dilihat dari rumusan norma semata, akan tetapi melihat nilai yang terkandung didalamnya yang membuat suatu tatanan masyarakat menjadi lebih baik. Masyarakat Indonesia memang memili pemahaman yang berbeda terkait norma kesusilaan, akan tetapi berdasarkan negara Pancasila maka nilai-nilai Ketuhanan tetap harus menjadi pedoman.

Salah satu penyebab dari hukum pidana repesif adalah adanya pemahaman yang sempit dari hukum, dimana hukum selalu di representasikan sebagai undang-undang, dan kepastian disejajarkan dengan kepastian undangundang (Ridwan, 2012). Sebagaimana berlaku dalam masyarakat Madura, nilai-nilai adat begitu menjiwai semua aspek kehidupan masyarakatnya terutama dalam hal kesusilaan. Masyarakat Madura menekankan "mon oreng riya benni bagusse, tape tatakramana, sanajian bagus tapi tatakrama jube, ma'celep ka ate" (yang penting bukan ketampanan atau kecantikan namun tata kramanya) (Christianto, 2016). Pertimbangan baik dan tidak baik tidak lagi berada pada tataran keinginan namun pada prinsip hidup menyangkut kehormatan diri yang dijunjung tinggi.

Berdasarkan hasil penelitian, Latief Wiyata menunjukan bahwa gangguan terhadap istri 
Law Reform

Volume 15, Nomor 1, Tahun 2019
Program Studi Magister IImu Hukum

Fakultas Hukum Universitas Diponegoro penyebab utama dilakukannya carok dengan prosentase perkara dari tahun 1990 sebanya 21 perkara (67,7\%), tahun 1991 sebanyak 23 perkara (71,9\%), tahun 1992 sebanyak 26 perkara (72,2\%), tahun 1993 sebanyak 28 perkara (50,9\%) dan tahun 1994 sebanyak 27 perkara (50,9\%) (Christianto, 2016).

Kasus di atas menunjukan masih adanya perkara kesusilaan yang membuat masyarakat melakukan carok. Apabila ketentuan pidana yang ada dalam aturan perundang-undangan tidak memberikan keadilan, maka budaya seperti carok akan tetap dilakukan termasuk di wilayah Indonesia yang lain dengan cara yang berbeda-beda. Padahal, sejak awal pendiri bangsa menekan bahwa Negara Kesatuan Republik Indonesia didirikan untuk mewujudkan masyarakat Indonesia yang sejahtera. Pengertian Negara Kesehjateraan yang dianut di Indonesia menuntut terpenuhinya kebutuhan Materiil maupun spiritual (Seomarsono, 2007).

Merumuskan suatu ketentuan pidana dalam delik kesusilaan bukanlah hal yang mudah, mengingat banyaknya perbedaan pendapat dan juga batasan-batasan negara dalam mengaturnya. Prof. Mr. Roeslan Saleh pernah melontarkan bahwa pengertian kesusilaan hendaknya tidak dibatasi pada pengertian kesusilaan dalam bidang seksual, tetapi meliputi hal-hal lain yang termasuk dalam penguasaan norma-norma kepatutan bertingkah laku dalam pergaulan masyarakat (Arief, 2011).
KUHP sendiri telah mengatur delik kesusilaan yang terbagi di Buku Kedua Bab XIV dan Buku Ketiga Bab VI. Hampir setiap pasal-pasal dalam KUHP termasuk delik kesusilaan mewarisi kaidah-kaidah yang mengatur hukum pidana semenjak masa kolonial hingga saat ini. Ruang lingkup tindak pidana kesusilaan dalam KUHP meliputi perbuatan atau tulisan yang melanggar kesusilaan (Pasal 281 - 283, 532 -535); hubungan seksual dan perbuatan cabul (Pasal 284 - 296), Perdagangan wanita dan anak laki-laki di bawah umur (Pasal 297); perbuatan yang berhubungan dengan pengguguran kehamilan (Pasal 299); yang berhubungan dengan minuman keras/memabukkan (Pasal 300, 536 - 539); Pemanfaatan anak untuk pengemisan, pekerjaan berbahaya/merusak kesehatan (Pasal 301); Penganiayaan ringan dan perlakukan tidak susila terhadap hewan (Pasal 302, 541 dan 544); perjudian (Pasal 303 dan 303 bis); meramal nasib/mimpi dan yang berhubungan dengan jimat atau benda berkekuatan gaib (Pasal 545 - 547).

Pasal-pasal kesusilaan di atas haruslah dikaji makna dan nilai yang terkandung didalamnya, mengingat pasal-pasal tersebut adalah peninggalan kolonial, sedangkan saat ini Indonesia berlandaskan nilai-nilai Pancasila. Barda Nawawi Arief (Arief, 1994) mengatakan Adanya kesenjangan / ketidaksesuaian (gap/discrepency) dan bahkan perbedaan nilai/kepentingan inilah yang tidak mustahil menjadi faktor timbulnya 
Law Reform

Volume 15, Nomor 1, Tahun 2019
Program Studi Magister IImu Hukum

Fakultas Hukum Universitas Diponegoro ketidakpuasan dalam praktek penegakan hukum. Bahkan dapat pula menjadi faktor penyebab timbulnya korban (faktor victimogen) maupun timbulnya delik/kejahatan lain (faktor criminogen).

Kongres PBB mengenai "The Prevention of Crime and the Treatment of Offenders" sering menyatakan dan mensinyalir, bahwa sistem hukum pidana yang ada selama ini di beberapa negara, yang sering berasal (diimpor) dari hukum asing semasa zaman kolonial, pada umumnya telah usang dan tidak adil (obselete and unjust) serta sudak ketinggalan zaman dan tidak sesuai dengan kenyataan (out moded and unreal) karena tidak berakar pada nilai-nilai budaya dan bahkan ada "diskrepansi" dengan aspirasi masyarakat serta tidak responsif terhadap kebutuhan sosial masa kini (Arief, 1994).

Ketentuan-ketentuan pidana yang diatur dalam Bab XIV mengenai kejahatan-kejahatan terhadap kesusilaan ini awalnya sengaja dibentuk oleh pembentuk undang-undang dengan maksud untuk melindungi orang-orang dari tindakantindakan asusila dan perilaku-perilaku baik dengan ucapan maupun dengan perbuatan yang menyinggung rasa susila karena bertentangan dengan pandangan orang tentang kepatutankepatutan dibidang sosial, baik ditinjau dari segi pandangan masyarakat setempat maupun dari segi kebiasaan masyarakat dalam menjalankan kehidupan seksual mereka (Lamintang, 2011).
Seiring berjalannya waktu, nilai-nilai dalam delik kesusilaan ternyata banyak yang bertentangan dengan nilai-nilai masyarakat yang sangat religi. Penelitian yang dilakukan oleh Latief Wiyata sebagaimana disebutkan di atas, menunjukan bahwa aturan terkait tindak pidana kesusilaan belumlah berkeadilan religius sehingga membuat masyarakat masih tidak lagi mempercayai hukum.

Secara lebih mendasar KUHP memang memiliki jiwa yang berbeda dengan jiwa bangsa Indonesia, hal ini jika dipaksakan akan berbenturan dengan nilai dan kepentingan baru yang tidak mustahil justru akan menimbulkan kejahatan baru. Masalah delik perzinahan merupakan salah satu contoh aktual adanya benturan antara pengertian dan paham tentang zina dalam KUHP dengan kepentingan/nilai sosial masyarakat. Adanya benturan tersebut justru menjadikan hukum tidak menghasilkan kemanfaatan dan keadilan yang melindungi masyarakat.

Pasal 284 KUHP menyatakan bahwa yang dikatakan perbuatan zina hanya pada seseorang yang telah menikah, hal tersebut tentu sangat bertentangan dengan nilai-nilai agama dan nilainilai hukum yang hidup diyakini sebagian masyarakat Indonesia.

Masalah delik perzinahan merupakan salah satu contoh aktual adanya benturan antara pengertian dan paham tentang zina dalam KUHP dengan kepentingan/nilai sosial masyarakat. 
Law Reform

Volume 15, Nomor 1, Tahun 2019
Program Studi Magister IImu Hukum

Fakultas Hukum Universitas Diponegoro
Benturan yang sering terjadi di masyarakat, acapkali menimbukalkan kejahaan baru (Bahriej, 2003).

Perbuatan zina sesungguhnya bukan hanya permasalahan dari pihak pelaku semata, akan tetapi masyarakat pun merasakan dampaknya. Sehingga hukum yang berbasis nilai keadilan religius harus memiliki keseimbangan dalam melihat suatu aturan ketentuan pidana, dengan berpedoman pada tuntunan Tuhan (dalam hal ini penulis merujuk pada Al-Qur'an) serta nilai moral yang berlaku di masyarakat. Sehingga masyarakat merasa terlindungi dengan adanya ketentuan pidana dalam suatu perundang-undangan.

Berdasarkan hasil wawancara penulis dengan Dr. Zaim Elmubarok, M.Ag, beliau mengatakan bahwa aturan terkait ketentuan pidana yang ada dalam KUHP sekarang belum bisa dikatakan berkeadilan religius. Banyaknya nilai-nilai luhur masyarakat yang masih sangat religius akhirnya terciderai oleh asas-asas hukum yang berasal dari kolonial. Lebih lanjut beliau mengatakan bahwa Adil itu menembus batas, sehingga adil itu tidak lagi memandang suku, agama maupun ras, sehingga adil itu sama.

Adil menurut Islam sangat bergandengan erat dengan Ikhsan, sedangkan Ikhsan menjadikan seseorang itu menjadi ber-Taqwa. Oleh sebab itu, menurutnya bahwa suatu ketentuan pidana yang berkeadilan religius adalah sesuai dengan nilai-nilai yang ada dalam Kitab Suci yang mana mampu melindungi masyarakat dan korban, selain itu memberikan perbaikan kepada pelaku.

Tindak pidana perzinahan atau overspel yang dimaksudkan dalam Pasal 284 ayat (1) KUHP merupakan suatu opzettlijk delict atau suatu tindak pidana yang harus dilakukan dengan sengaja. Itu berarti unsur kesengajaan tersebut harus terbukti ada pada diri pelaku, agar ia dapat dinyatakan terbukti telah memenuhi unsur kesengajaan dalam melakukan tindak pidana perzinahan yang diatur dalam Pasal 284 ayat (1) angka 1 huruf a atau b dan angka 2 huruf a atau b KUHP. Jika unsur kesengajaan dalam bentuk kehendak atau dalam bentuk maksud untuk melakukan perzinahan pada diri pelaku ternyata tidak dapat dibuktikan, maka Hakim akan memberikan putusan bebas dari tuntutan hukum atau ontslag van rechtsvervloging bagi pelaku (Lamintang, 2011).

Di dalam rumusan ketentuan pidana yang diatur Pasal 284 ayat (1) angka 1 huruf a dan angka 2 huruf b KUHP, undang-undang telah mensyaratkan adanya pengetahuan para pelaku yakni bahwa ketentuan yang diatur dalam Pasal 27 Burgelijk Wetboek itu berlaku bagi dirinya atau berlaku bagi laki-laki dengan siapa seorang wanita itu telah melakukan perzinaan.

Jika di sidang pengadilan yang memeriksa perkara pelaku, pengetahuan tentang berlakunya ketentuan yang diatur dalam Pasal 27 Burgelijk Wetboek ternyata tidak dapat dibuktikan oleh Penuntut Umum atau oleh hakim, maka hakim 
Law Reform

Volume 15, Nomor 1, Tahun 2019
Program Studi Magister IImu Hukum

Fakultas Hukum Universitas Diponegoro harus memberikan putusan bebas atau vrispraak bagi pelaku (Lamintang, 2011).

Rumusan pasal ketentuan pidana di atas sangat bertentangan dengan nilai-nilai Pancasila berdasarkan Ketuhanan Yang Maha Esa. Hukum seakan hanya memberikan perlindungan kepada para pelaku, nilai-nilai religius yang ada dalam masyarakat pun menjadi terganggu. Masyarakat tidak dapat melakukan perbuatan apapun karena hal tersebut dibenarkan dalam peraturan. Ketentuan pidana seperti itu menunjukan bahwa hukum yang berlaku belumlah berkeadilan religius.

Pasal 284 KUHP menunjukan bahwa keadilan yang sesungguhnya belumlah terwujud dalam ketentuan pidana yang berlaku. Di dalam berbagai rambu-rambu nasional, sering juga diungkapkan, bahwa keadilan yang ditegakkan adalah keadilan substantif, yaitu "Keadilan berdasarkan Pancasila" atau "Keadilan berdasarkan Ketuhanan YME (Pasal 2 ayat 2 UU No. 48/2009). Jadi tidak digunakan istilah "keadilan berdasarkan UU". Ini berarti tidak ada sekularisme dalam penegakan hukum di Indonesia, di samping pengenaan pidana harus berdasar tuntunan UU, harus juga dilandasi oleh tuntunan Tuhan dalam menegakkan keadilan (Arief, 2012).

Pada kasus kesusilaan tentang zina ini, rumusan ketentuan pidana sangat berpihak hanya kepada perbuatan pelaku semata tanpa memperhatikan keadilan yang ada di masyarakat dan norma-norma yang berlaku (norma agama, norma kesopanan). Pasal-pasal dalam KUHP juga tidak bisa menghukum/melarang perbuatan seorang pria yang telah mengadakan hubungan kelamin dengan seorang wanita yang menikah, dengan sepertujuan atau dengan sepengetahuan suami dari wanita tersebut tidak dapat dipandang sebagai perzinaan. Hal ini dapat dilihat Hoge Raad dalam arrest-nya tanggal 16 Mei 1946, NJ 1946 No. 523 antara lain memutuskan bahwa (Lamintang, 2011):

"Onder overspel is niet begrepen vleeselijk gemeenschap met een derde onder goedkeuring van den anderen echtgenoot. De daad is dan geen schending van de huwelijkstrouw. I.c was de man souteneur; hij had zijn vrouw tot publiek vrouw gemaakt. Hij keurde haar levenswijze zonder voorbehoud goed".

"(Tidak termasuk dalam pengertian zina yakni mengadakan hubungan kelamin dengan pihak ketiga, yang dilakukan dengan persetujuan suami dari pihak ketiga tersebut. Perbuatan itu bukan merupakan yang menodai kesetiaan dalam perkawinan. Dalam hal ini, suami tersebut merupakan seorang germo, yang telah membuat istrinya menjadi seorang pelacur. Ia telah menyetujui cara hidup yang ditemput oleh istirnya tanpa syarat)".

Perbuatan di atas tidak sesuai dengan nilainilai Pancasila. Menurut Barda Nawawi Arief, hukum yang berkeadilan adalah tidak bisa hanya melihat tekstual yang ada dalam pasal semata, apalagi di negara Pancasila yang berdasarkan Ketuhanan Yang Maha Esa. Hukum harus berdasarkan tuntunan Tuhan, selain itu Barda Nawawi Arief juga mengatakan bahwa hukum tidak 
boleh terjebak pada asas legalitas yang kaku, yang hanya melihat perbuatan dinyatakan bersalah atau tidak hanya yang tertulis, tapi mengabaikan hukum yang hidup di masyarakat dan tuntunan Tuhan. Hukum yang berkeadilan harus memiliki nilai keseimbangan, yakni keseimbangan antara aturan yang berlaku dengan hukum yang hidup di masyarakat. Keseimbangan juga tidak hanya berfokus kepada pelaku/perbuatan semata yang tertulis dalam rumusan pasal, tetapi ada hak-hak masyarakat juga yang harus dilindungi kepentingannya.

Perbuatan Zina yang dirumuskan dalam Pasal 284 KUHP yang mana tidak melarang seorang yang telah terikat perkawinan melakukan hubungan seksual asal dengan persetujuan suami/istri adalah tidak sesuai dengan nilai-nilai agama. Dalam Surat An-Nur dikatakan yang artinya:

"Katakanlah kepada laki-laki yang beriman, agar mereka menjaga pandangannya, dan memelihara kemaluannya; yang demikian itu lebih suci bagi mereka. Sungguh, Allah Maha mengetahui apa yang mereka perbuat (Q.S. 24 ayat 30$) "$.

"Dan katakanlah kepada perempuan yang beriman, agar mereka menjaga pandangannya, dan memelihara kemaluannya, dan janganlah menampakkan perhiasannya (auratnya), kecuali yang (biasa) terlihat. dst (Q.S 24 ayat 31)".

Ayat diatas menunjukan bahwa seorang manusia haruslah memelihara diri dari perbuatanperbuatan yang dilarang. Zaim El-Mubarok (wawancara) mengatakan bahwa hukum yang baik dan adil seharusnya menjadikan seseorang manusia menjadi ber Taqwa, sehingga apabila rumusan suatu teks pasal itu justru bertentangan dengan moral maka hukum itu tidak bisa dikatakan baik, apalagi bisa memberikan keadilan.

\section{Kebijakan Formulasi Ketentuan Pidana Yang Berkeadilan Religius}

Merumuskan ketentuan pidana yang berbasis nilai keadilan religius haruslah memiliki pengetahuan tentang nilai-nilai religius dan keadilan itu sendiri. Barda Nawawi Arief (Arief, 2007) mengatakan bahwa hakikat pembaruan/ pembangunan hukum bukan terletak pada aspek formal dan lahiriah (seperti terbentuknya UU baru), melainkan justru terletak pada aspek immateril ini, yaitu membangun budaya dan nilai-nilai kejiwaan dari hukum. Selain itu, pembangun dalam bidang bidang hukum khususnya pembangunan hukum pidana, tidak hanya mencakup pembangunan yang bersifat struktural, yakni pembangunan substansial berupa produk-produk yang merupakan hasil suatu sistem hukum dalam peraturan hukum pidana yang bersifat kultural (Jaya, 2016).

Disamping peningkatan kualitas moral, penegakan keadilan memerlukan peningkatan kualitas keilmuan. Kebijakan legislatif/formulatif (dalam rangka reformasi penyusunan UU) perlu disertai dengan reformasi kualitas keilmuannya (ilmu hukum dan keadilan). Sebagai negara yang berlandaskan Pancasila yang ber-Ketuhanan, maka 
dalam merumuskan suatu aturan ketentuan pidana harus mengikuti pedoman/ tuntunan ilahiah (tuntunan Tuhan Yang Maha Esa) tentang bagaimana merumuskan aturan yang berkeadilan religius. Dalam Al-Quran terdapat tuntunan yang menyatakan antara lain:

a. "Apabila kamu menghukum di antara manusia ("bainan naas"), maka hukumlah dengan adil" (Q.S. an-Nisa': 58);

b. "Tegakkanlah kebenaran dan keadilan walau pada dirimu sendiri, ayah ibumu, maupun pada karib kerabat (kroni-kroni)mu" (Q.S. an-Nisa': 135)

c. "Janganlah karena mengikuti hawa nafsumu karena ingin menyimpang dari kebenaran/keadilan" (Q.S. an-Nisa': 135)

d. "Janganlah kebencianmu kepada suatu kaum/golongan, mendorong/menyebabkan kamu berlaku tidak adil" (Q.S. Al-Maidah: 8).

Tuntuan keadilan menurut Al-Quran di atas jelas mengandung prinsip-prinsip universal, yaitu: prinsip persamaan (equality, indiskriminatif); tidak pilih kasih (nonfavoritisme, anti nepotisme); tidak berpihak pada pihak (fairness, impartial); dan prinsip objektivitas (tidak subjektif). Prinsip/ nilainilai universal itu, saat ini terlihat semakin melemah atau mengalami erosi (Arief, 2007).

Peningkatan kualitas para penegak hukum terhadap tuntunan keadilan berdasarkan Ketuhanan Yang Maha Esa di atas, tentunya tidak hanya sebatas kemampuan "pengetahuan" (knowledge/cognitive) saja, tetapi diharapkan menjiwai keyakinan dan sikapnya, bahwa apabila keadilan berdasarkan tuntunan ilahiah itu tidak diikuti dan dilaksanakan, maka akan rusaklah masyarakat (Arief, 2007).

Al-Quran menggunakan beberapa kata yang berbeda untuk makna keadilan, yaitu qist, mizan, haq, watasha, dan adl. Kesemua kata tersebut dalam makna yang berbeda dapat ditujukan pada makna adil atau keadilan. Kata qist mengandung makna keadilan yang dikaitkan dengan kebenaran. Kata haq, yaitu kebenaran dapat juga bermakna keadilan (Q.S 7:159 dan 181). Mizan mengandung makna keadilan berkaitan dengan timbangan (keseimbangan), yaitu memperlakukan sesuatu secara seimbang. Kata watasha yaitu keadilan dalam kaitan dengan sikap yang berada ditengah (pertengahan) dan tidak memihak (Zoelva, 2018).

Pendekatan nilai religius dalam pembaharuan substansi hukum (ketentuan pidana) telah berulang kali dikemukakan oleh para sarjana maupun dalam berbagai forum seminar hukum nasional. Biasanya pendekatan religius dikaitkan juga dengan pendekatan nilai-nilai budaya dan kesadaran hukum yang hidup dalam masyarakat (hukum adat). berbagai statement seminar nasional mengenai pendekatan kultural-religius itu (khususnya yang berkaitan dengan hukum pidana) antara lain (Arief, 2012) :

1) Seminar Hukum Nasional ke-I/1963. Yang dipandang sebagai perbuatan jahat....., tidak menutup pintu bagi larangan perbuatan menurut hukum adat yang hidup dan tidak menghambat pembentukan masyarakat, yang dicita-citakan tadi, dengan sanksi adat yang masih dapat sesuai dengan martabat bangsa. Bagian khusus antara lain memuat : menciptakan delik-delik 
agama, antara lain blasphemy. Unsur-unsur hukum agama dan hukum adat dijalinkan dalam KUHP

2) Simposium "Pengaruh Kebudayaan/Agama Terhadap Hukum Pidana Khusus" 1975:

Kesimpulan Komisi I. Dalam memperhitungkan pengaruh-pengaruh kebudayaan dan agama dalam penciptaan hukum pidana, diperlukan pembentukan delik-delik agama dan delik-delik yang ada hubungannya dengan agama serta delik adat. Dalam menetapkan delik-delik susila supaya diperhatikan faktor-faktor agama, adat serta modernisasi dan dalam penerapannya diperhitungkan nilai-nilai umum yang berlaku dalam masyarakat.

Kesimpulan Komisi II : pengaruh/unsur agama memegang peranan dalam menentukan normanorma hukum pidana; antara norma adat dan agama tidak dapat dibedakan dalam delik adat; norma agama/adat dalam kenyataannya sudah bersatu dengan putusan hakim sehari-hari; pengaruh agama di beberapa daerah telah menjelma menjadi kesadaran hukum rakyat;

3) Seminar Hukum Nasional ke IV Tahun 1979. Hukum Nasional dibina ke arah unifikasi dengan memperhatikan kesadaran hukum masyarakat.

Hasil seminar dan simposium di atas menunjukan bahwa segala ketentuan pidana yang ada di Indonesia tidak bisa dilepaskan dari pengaruh nilai-nilai agama dan hukum yang hidup di masyarakat. Oleh sebab itu, para legislator dalam merumuskan ketentuan pidana yang akan datang haruslah mampu menggali dan memasukan nilai-nilai agama serta hukum adat ke dalam rumusan Pasal. Dengan demikian harapan agar terciptanya keadilan yang religius dapat terwujud. Selama ini, banyaknya perkara-perkara yang mana dalam penyelesainya dianggap belumlah berkeadilan, hal tersebut disebabkan salah satunya yaitu ketentuan pidana yang masih berlandaskan hukum kolonial, sehingga sering terjadi benturan antara kepastian hukum dan keadilan.

Kesimpulan Seminar Hukum Nasional keVI/1994 pernah dinyatakan: "perlu untuk dikembangkan gagasan mengenai kualitas pemberian keadilan (the dispension of justice) yang lebih cocok dengan sistem hukum Pancasila". Dari pernyataan ini tersmpul perlunya dikembangkan keadilan bercirikan Indonesia yaitu "keadilan Pancasila", yang mengandung makna "keadilan berketuhanan", keadilan berkemanusiaan (humanistik)", "keadilan yang demokratik, nasionalistik, dan berkeadilan-sosial. Ini berarti keadilan yang ditegakkan juga bukan sekedar keadilan formal, tetapi keadilan substansial (Arief, 2012).

Perumuskan formulasi yang berkeadilan religius, maka para pembuat undang-undang harus mampu menggali petunjuk yang ada dalam kitab suci agama (Al-Quran) dan nilai-nilai hukum yang hidup di masyarakat. Dengan menggali kedua sumber tersebut, maka kemungkin terjadi benturan antara hukum tertulis dengan hukum yang hidup tidak akan terjadi. Untuk menyatukan formulasi hukum tertulis dan menggali nilai-nilai agama, maka dibutuhkan nilai-nilai keseimbangan.

Pada kasus delik perzinahan, maka hal konkret yang harus dilakukan oleh para legislator dalam merumuskan ketentuan pidana terkait perzinahan adalah dengan memperluas makna 
Law Reform

Volume 15, Nomor 1, Tahun 2019
Program Studi Magister IImu Hukum

Fakultas Hukum Universitas Diponegoro perzinahan itu sendiri yang berpedoman kepada Al-

Quran. Hal tersebut memiliki nilai keseimbangan dan keadilan, dengan memperluas makna defizini zina tersebut akan memberikan keadilan bagi masyarakat Indonesia yang religius, sehingga nilai keseimbangan antara kepentingan masyarakat dan nilai-nilai agama dapat terlindungi oleh ketentuan pidana yang berlaku.

Sebagai contoh, masih banyak perbuatan yang dianggap melanggar menurut nilai-nilai agama (Islam) yang tidak diadopsi dalam ketentuan pidana yang berlaku. Sebagaimana dijelaskan di atas, bahwa formulasi ketentuan pidana yang berbasis nilai keadilan religius dalam Al-Quran diantaranya harus mengandung makna Mizan: keadilan berkaitan dengan timbangan (keseimbangan), yaitu memperlakukan sesuatu secara seimbang. Kata watasha yaitu keadilan dalam kaitan dengan sikap yang berada ditengah (pertengahan) dan tidak memihak. Jika merujuk pada makna keadilan menurut Al-Quran, maka masih banyak formulasi ketentuan pidana yang belum berbasis nilai keadilan religius.

Perbuatan "kumpul kebo" yang sangat populer di masyarakat yang untuk menyebut perbuatan hidup bersama di luar pernikahan yang sah, menurut KUHP yang berlaku saat ini, yang berasal dari Wetboek van Strafrecht (WvS) zaman Hindia Belanda, kumpul kebo tidak dinyatakan sebagai perbuatan yang dapat dipidana. Padahal perbuatan tersebut dipandang oleh sebagian besar masyarakat Indonesia sebagai perbuatan tercela. Selain itu, berdasarkan nilai-nilai religius perbuatan tersebut adalah perbuatan tercela yang tidak boleh dilakukan. Berbagai istilah, kumpul kebo ini dapat diidentifikasi dengan sebutan "samen leven", "living in nonmatriamonial union", conjugal union", atau "cohabitation" (Arief, 2011).

Indonesia adalah negara berdasarkan Pancasila, yang mana sila pertama menyatakan "Ketuhanan Yang Maha Esa", sila tersebut seharusnya menjadi acuan dalam merumuskan ketentuan pidana. Mengingat Pancasila adalah sumber dari segala aturan perundang-undangan di Indonesia. Kumpul kebo merupakan suatu realitas sosial dan memunculkan problema sosial, tetapi sampai saat ini tidak ada aturan yang mengaturnya dan belum terjamah hukum.

Saat ini tindak pidana kumpul kebo dimasukan dalam rangcangan KUHP. Banyak terjadi pro kontra. Banyak yang berpendapat bahwa Negara tidak perlu ikut campur dalam urusan pribadi, akan tetapi disisi lain banyak juga masyarakat yang merasa bahwa itu harus diatur, apalagi perbuatan tersebut bertentangan dengan nilai-nilai agama.

Memperluas definisi zina dengan merujuk pada Al-Quran adalah hal yang harus dilakukan, dengan diaturnya perbuatan kumpul kebo adalah wujud ketentuan pidana yang berbasis nilai keadilan religius, dikarenakan mampu mengadopsi nilai-nilai yang dianut masyarakat. Perluasan 
Law Reform

Volume 15, Nomor 1, Tahun 2019
Program Studi Magister Ilmu Hukum

Fakultas Hukum Universitas Diponegoro makna zina dengan merujuk pada Al-Quran mengingat hampir sebagian besar masyarakat Indonesia beragama Islam, selain itu dengan memperluas dan mewadahi perbuatan kumpul kebo kedalam aturan perundang-undangan, diharapkan dapat menghindarkan dari perbuatan main hakim sendiri dikarenakan hilangkan kepercayaan masyarakat terhadap hukum.

Aturan ketentuan pidana yang seirama dengan nilai yang dianut masyarakat (nilai religius) mampu menjadikan hukum itu bermanfaat dan berkeadian. Sebagaimana seorang ahli hukum Von Savigny pernah menyatakan bahwa sistem hukum tidak ahistoris, hukum justru muncul dan berkembang bersama masyarakat (Cahyadi, 2005).

Bila melihat ketentuan pidana di beberpa negara, tindak pidana kumpul kebo sesungguhnya telah diatur diberbagai negara diantaranya (Barda, 2011):

a. KUHP Republik Federal Yugoslavia

KUHP Republik Federal Yugoslavia 1951, Pasal 193 merumuskan sebagai berikut:

(1)A person of full age living in nonmatrimonial union with a minor who has attained the age of fourteen years, shall be punished with imprisonment of not less than three months.

(2) The same punishment shall be inflicted on the parent or guardian prmitted a minor over fourteen years old to live in nonmatrimonial union with another person, or who induced him to do so

(3) If the offence from Paragraph 2 of this article was commited for personal gain, the offender shall be punished with severe imprisonment of to five years.
(4) If marrige is contracted, prosecution shall not be instituted and if it has been isntituted, it shall be discontinuned.

Dari perumusan di atas, terlihat hal-hal sebagai berikut:

(1) Yang dipidana adalah kumpul kebo antara orang dewasa dan anak yang telah mencapai usia 14 (empat belas) tahun; pidananya tidak kurang dari tiga bulan penjara (Catatatan: menurut sistem perumusan di Yugoslavia, apabila minimum pidana ditulis "not less than three months", berarti edlik itu diancam dengan pidana mulai dari tiga bulan sampai maksimum tiga bulan, lihat Pasal 30 KUHP Yugoslavia. Jadi mirip dengan sistem perumusan di Norwegia dan Polandia)

(2) Pidana yang sama juga dikenakan kepada orang tua atau wali yang mengizinkan atau mendorong/membujuk anak di atas empat belas tahun untuk kumpul kebo dengan orang lain.

(3) Apabila ayat (2) dilakukan untuk keuntungan pribadi, maksimum pidananya lima tahun penjara berat ("severe imprisonment").

(4) Apabila perkawinan berlangsung, penuntutan tidak dilakukan; dan apabila telah dilakukan penuntutan penuntutan itu tidak dilanjutkan.

b. KUHP Singapore dan Malaysia

Dalam Bab XX tentang Offences Relating to Marriage, ada pasal yang mengancam pidana terhadap seorang laki-laki yang hidup bersama sebagai suami istri (cohabitation) atau melakukan hubungan seksual dengan seorang wanita yang karena ditipu telah percaya bahwa ia (wanita itu) telah kawin secara sah dengan laki-laki itu (Pasal 493)

Pasal 493 KUHP Singapore berbunyi:

"Every man, who by deceit causes any women who is not lawfully married to him to believe that she is lawfully married to him 
Law Reform

Volume 15, Nomor 1, Tahun 2019
Program Studi Magister IImu Hukum

Fakultas Hukum Universitas Diponegoro and tho cohabit or have sexual intercourse with him in that belief, shall be punished with imprisoment for a term which may extent to ten years, and shall also be liable to fine".

"Sa-saorang lelaki yang dengan jalan perdayaan menyebabkan sa-saorang perempuan yang tidak berkahwin dengannya dengan sah disisi undang-undang supaya memperchayai bahawa perempuan itu telah berkahwin dengan-nya dengan sah di-sisi undang-undang dan supaya bersekedudokan atau bersetuboh dengannya atas kepercayaan itu, hendaklah diseksa dengan penjara sa-lama tempoh yang boleh sampai duapuloh (sic) tahun, dan boleh-lah juga di-kenakan denda".

(Di-Indonesiakan:

"seorang laki-laki yang dengan cara memperdaya/menipu seorang wanita yang tidak terikat dalam perkawinan yang sah dengannya menurut undang-undang, sehingga percaya bahwa telah menikah secara sah dengan laki-laki itu, dan hidup bersama atau melakukan persetubuhan dengannya atas kepercayaan tersebut, diancam pidana penjara selama tidak lebih dari 20 (sic. 10 tahun) dan juga denda". BNA)

Diaturnya masalah kumpul keboo di berbagai KUHP negara lain, menunjukan bahwa negara lain (asing) juga mengurusi masalah moral dan rasa kesusilaan masyarakat. Jadi tidak benar adanya pendapat bahwa negara tidak berhak untuk mengurusi moral dan rasa kesusilaan masyarakat.

(D.A Thomas pernah menyatakan Arief, 2011):

"Systems of substantive criminal law serve several purpose. Politically, a criminal code may acquire symbolic significance as an expression of national unity. Morally, the code may amount to a concrete manifestation of the judgment of the community on the central values which bind it together and serve notice on the citizen of the limits of permissible behaviour within that society. Pragmatically, a code of substantive criminal law is a means of defining the collective powers of the various organs of the state concerned with the maintence of order, and of allocating their respective sphere of responsibility".

Sistem hukum pidana substantif (KUHP) secara politik pada hakikatnya merupakan ciri simbolik dari ekspresi/pernyataan kesatuan nasioanl dan secara moral merupakan perwujudan/manifestasi penilaian masyarakat terhadap nilai-nilai sentral yang mengikat dan membatasi perilaku anggota masyarakat. Pernyataan D.A Thomas di atas sangat sesuai dengan kondisi Indonesia yang sistem hukumnya dilandaskan pada nilai-nilai Pancasila, khususnya sila Ketuhanan Yang Maha Esa yang mengandung di dalamnya nilai-nilai/paradigma moral religius (Arief, 2011).

Ketentuan pidana yang berkeadilan religius adalah, ketentuan pidana yang mana dalam rumusannya memasukkan nilai-nilai religi yang berpedoman kepada Tuntunan Tuhan. Apabila dalam rumusan pasal saja nilai-nilai religi itu tidak ditemukan, maka tidak mungkin hukum akan menghasilkan keadilan yang religius.

Nilai keseimbangan menjadi sangat penting bagi para legislator dalam merumuskan ketentuan pidana yang berkeadilan. Nilai keseimbangan tersebut diantaranya: Keseimbangan dalam menentukan sumber/dasar hukum ditetapkannya pidana. Selama ini, ketentuan pidana yang berlaku 
hanya memberi ruang kepada hukum yang tertulis, sehingga banyak perbuatan yang menurut hukum agama dan adat adalah terlarang, tidak bisa dijerat oleh hukum tertulis. Hal tersebut sesuai dengan fungsi hukum yang menurut Hans Kelsen adalah untuk menciptakan keadilan bagi masyarakat dimana konsep adil dipahami sebagai suatu penciptaan terhadap sebanyak-banyaknya kebahagiaan dalam masyarakat (Gunarto, 2012).

Formulasi ketentuan pidana yang berkeadilan religius, dalam menentukan pidana haruslah memiliki tujuan pidana. Sesuai dengan politik hukum pidana, maka tujuan pemidanaan harus diarahkan kepada perlindungan masyarakat dari kejahatan serta keseimbangan dan keselarasan hidup dalam masyarakat dengan memperhatikan kepentingan - kepentingan masyarakat / negara, korban dan pelaku.

Tujuan pemidanaan sangat mempengaruhi dalam penekan hukum, sehingga keadilan sering terabaikan. Barda Nawawi Arief (Arief, 2017) berpendapat bahwa, tujuan pemidanaan harus dikaitkan dengan 4 (empat) aspek atau ruang lingkup perlindungan dari perlindungan masyarakat, yaitu: (1) Masyarakat memerlukan perlindungan terhadap perbuatan anti sosial yang merugikan dan membahayakan masyarakat. Bertolak dari aspek ini, maka tujuan pemidanaan (penegakan hukum pidana) adalah mencegah dan menanggulangi kejahatan; (2) Masyarakat memerlukan perlindungan terhadap sifat berbahaya seseorang.
Oleh karena itu, pidana/hukum pidana bertujuan memperbaiki sipelaku kejahatan atau berusaha mengubah dan mempengaruhi tingkah lakunya agar kemabli patuh pada hukum dan menjadi warga masyarakat yang baik dan berguna; (3) Masyarakat memerlukan pula perlindungan terhadap penyalahgunaan sanksi atau reaksi dari penegakan hukum maupun dari warga masyarakat pada umumnya. Oleh karena itu wajar pula akibat tujuan pidana harus mencegah terjadinya perlakuan atau tindakan yang sewenang-wenang di luar hukum (tidak manusiawi); (4) Masyarakat memerlukan perlindungan terhadap keseimbangan atau keselarasan berbagai kepentingan dan nilai yang terganggu sebagai akibat dari adanya kejahatan. Oleh karena itu wajar pula apabila penegakan hukum pidana harus dapat menyelesaikan konflik yang ditimbulkan oleh tindak pidana, dapat pula memulihkan keseimbangan dan mendatangkan rasa damai dalam masyarakat.

Bertolak dari keempat aspek tujuan perlindungan masyarakat seperti yang telah diuraikan di atas, maka tujuan pemidanaan pada intinya mengandung dua aspek pokok, yaitu (Arief, 2017):

1. Aspek perlindungan masyarakat terhadap tindak pidana.

Aspek pokok pertama ini meliputi tujuan-tujuan: (a). Pencegahan kejahatan, (b). Pengayoman (pengaman) masyarakat, (c). Pemulihan keseimbangan masyarakat, terdiri dari penyelesaian konflik (conflict oplossing) dan mendatangkan rasa damai (vrede - making). 
2. Aspek perlindungan/pembinaan individu pelaku tindak pidana (aspek individualisasi pidana) Aspek pokok kedua ini dapat meliputi tujuan : (a). Rehabilitiasi, reduksi, resosialisasi (memasyarakatkan) terpidana; antara lain : agar tidak melakukan perbuatan-perbuatan yang merusak atau merugikan diri sendiri maupun orang lain/masyarakat dan agar berbudi pekerti (berakhlak) Pancasila, (b). Membebaskan rasa bersalah, (c). Melindungi si pelaku dari pengenaan sanksi atau pembalasan yang sewenang-wenang tidak manusiawi (pidana tidak dimaksudkan untuk menderitakan dan merendahkan martabat manusia).

Zaim Elmubarok (wawancara) mengatakan bahwa, dalam merumuskan ketentuan pidana yang berkeadilan religius, selain menggali nilai-nilai tuntunan Tuhan. Maka moral menjadi tolak ukur rumusan ketentuan pidana. Zaim mengatakan bahwa Nabi Muhammad diturunkan oleh Allah, pertama kali yang diperintahkan adalah untuk memperbaik akhlak manusia, bukan memberikan hukuman. Oleh sebab itu dalam perumusan ketentuan pidana bisa dilihat dari substansi apakah memiliki keseimbangan, yaitu memperbaiki pelaku yang melakukan tindak pidana agar bisa menjadi lebih baik lagi. Selain itu tidak melupakan kepentingan korban dan masyarakat.

\section{SIMPULAN}

Berdasarkan pembahasan dan hasil analisis di atas, dapat ditarik kesimpulan: pertama, ketentuan pidana dalam delik kesusilaan yang berlaku saat ini belum berlandaskan nilai keadilan religius. Ketentuan pidana masih menerapkan nilainilai hukum peninggalan kolonial, belum ada nilai keseimbangan sebagai upaya terwujudnya nilai keadilan yang religius. Nilai-nilai hukum agama dan hukum yang hidup di masyarakat akhirnya terciderai oleh ketentuan pidana dalam delik kesusilaan, karena dianggap masih bersifat individual dan tidak sesuai dengan Pancasila. Kedua, ketentuan pidana yang berbasis nilai keadilan religius dalam delik perzinahan adalah dengan mempeluas makna zina yang ada dalam ketentuan pidana sekarang dengan merujuk pada kitab suci (Al-Quran), hal tersebut dikarenakan sebagian besar masyarakat Indonesia yang beragama Islam dan religius, selain itu hal tersebut merupakan bentuk pengamalan sila pertama Pancasila yang berdasarkan Ketuhanan Yang Maha Esa.

\section{DAFTAR PUSTAKA \\ BUKU}

Arief, Barda N. (2011). Bunga Rampai Kebijakan Hukum Pidana Perkembangan Penyusunan Konsep KUHP, Cetakan kedua. Jakarta: Kencana Prenada Media Group.

Arief, Barda N. (2007). Masalah Penegakan Hukum dan Kebijakan Hukum Pidana dalam Penanggulangan Kejahatan. Jakarta: Kencana Media Group.

Arief, Barda N. (2011). Pendekatan Keilmuan dan Pendekatan Religius dalam Rangka 
Optimalisasi dan Reformasi Penegakan Hukum (Pidana) di Indonesia. Semarang: Penerbit Universitas Diponegoro.

Arief, Barda N. (2017). Tujuan \& Pedoman Pemidanaan (Perspektif Pembaharuan \& Perbandingan Hukum Pidana. Semarang: Pustaka Magister

Arief, Barda N. (2011). Pembaharuan Hukum Pidana Dalam Perspektif Kajian Perbandingan. Bandung: PT Citra Aditya Bakti.

Arief, Barda N. (2012). Kebijakan Formulasi Ketentuan Pidana Dalam Peraturan Perundang-undangan, Semarang: Pustaka Magister.

Lamintang. (2011). Delik-delik Khusus: Kejahatan Melanggar Norma-norma Kesusilaan dan Norma Kepatutan. Jakarta: Sinar Grafika.

Soemitro, Ronny H. (2000). Metodologi Penelitian Hukum. Jakarta: Ghalia Indonesia.

\section{JURNAL}

Ayu, Hanuring., \& Suparwi. (2018). Perlindungan Hak Bagi Tersangka Dalam Kasus Tindak Pidana Kesusilaan. Jurnal Kajian Hukum, Vol. 3, (No.1), p.441-449.

Ali, M. (2016). Fondasi Imu Hukum Berketuhanan: Analisis Filosofis Terhadap Ontologi, Epistemologi, dan Aksiologi. J urnal Pandecta Unnes, Vol.11, (No.2), p.125.
Amin, M. (2014). Konsep Keadilan Dalam Perspektif Filsafat Hukum Islam. J urnal Hukum dan Perundangan Islam, Vol.4, (No.2), p.323.

Bahriej, A. (2003). Tinjauan Yuridis atas Delik Perzinahan (Overspel) dalam Hukum Pidana Indonesia. Jurnal Sosio-Relegia, Vol. 2, (No.2), p. 2

Cahyadi, A. (2005). Hukum Rakyat. Jurnal Hukum dan Pembangunan, Tahun ke-35 No.4, p.387.

Christianto, H. (2016). Norma Kesusilaan Sebagai Batasan Penemuan Hukum Progresif: Perkara Kesusilaan di Bangkalan Madura. J urnal Hukum \& Pembangunan, Tahun ke-46

No.1 Januari-Maret, pp.2-4.

Fajar, Indrawan., \& Busthami, M. Dachran S. (2018). Adultery in the Perspective of Islamic Law and the Criminal Law Legislation a Comparative Study. IOSR Journal Of Humanities And Social Science (IOSRJHSS), Vol.23, Issue 2, Ver. 1 (February. 2018), pp.51-55.

Gunarto, Marcus P. (2012). Asas Keseimbangan Dalam Konsep Rancangan Kitab UndangUndang Hukum Pidana. Mimbar Hukum, Vol.24, (No.1), p. 84

Jaya, Nyoman Sarekat P. (2016). Hukum (Sanksi) Pidana Adat Dalam Pembaharuan Hukum Pidana Nasional. Masalah-masalah Hukum, Jilid 45, (No.2), p.125. 
Law Reform

Volume 15, Nomor 1, Tahun 2019

Lumingkewas, F. (2016) Tindak Pidana Kesusilaan dalam KUHP dan RUU KUHP Serta Persoalan Keberpihakan Terhadap Perempuan. Lex Crimen, Vol.V, (No.1), p. 22.

Miller. A. (2018). Punishing Passion: A Comparative Analysis ofAdultery Laws in the United States of Americaand Taiwan and their Effects on Women. REGINA A. LOUGHRAN MEMORIAL ISSUE. Fordham International Law J ournal, Vol. 41, (Issue2) Article 4, pp.425-472.

Ridwan. (2012) Menciptakan Keadilan Dengan Penerapan Hukum Progresif Melalui Pendekatan IImu Ketuhanan. Kanun Jurnal IImu Hukum, No.57, Th.XIV, p. 250.

Soemarsono, M. (2007). Negara Hukum Indonesia ditinjau dari Sudut Teori Tujuan Negara. J urnal Hukum dan Pembangunan, Tahun ke37 No.2 April - Juni 2007, p.309.

Yudhanti, R. (2016). Pancasila dan Berbagai Permasalahan Aktual. Seminar Hukum Nasional, Vol.2, (No.1), p.600.

Yuniantoro, F. (2017). Eksploitasi Seksual Sebagai

Bentuk Kejahatan Kesusilaan Dalam

Peraturan Perundang-Undangan. J ustitia

Jurnal Hukum FH Universitas Muhamadiyah Surabaya Vo. 2 (No.1). P. 105-126

Zainal, A. (2017) Kesusilaan dan Pelecehan Seksual Ditinjau dari Kebijakan Hukum Pidana menulis tentang Kejahatan Kesusilaan dan Pelecehan Seksual Ditinjau dari Kebijakan
Program Studi Magister IImu Hukum Fakultas Hukum Universitas Diponegoro

Hukum Pidana. J urnal Al-Adl Vol. 7 (No.1). P. 138-153

Sekhri, A. (2014) The Good, The Bad, And The Adulterous: Criminal Law And Adultery In India. Socio-Legal Review, Vol 10, p. 47-64.

\section{PIDATO PENGUKUHAN}

Arief, Barda N. (1994). Beberapa Aspek Pengembangan IImu Hukum Pidana (Menyongsong Generasi Baru Hukum Pidana Indonesia). Pidato Pengukuhan Guru Besar dalam IImu Hukum, Undip.

Soponyono, E. (2017). Hikmah Al-Quran Dalam Pembaharuan Hukum Pidana Demi Mewujudkan Keadilan Religius, Semarang: Pidato Pengukuhan Guru Besar Dosen Tetap Undip.

\section{SUMBER ONLINE}

Zoelva, H. (2018). Kembali ke Fitrah Keadilan dalam Perspektif Islam dan Kebangsaaan. Retrieved from http://mediaindonesia.com/read/detail/1661 8-kembali-ke-fitrah-keadilan-dalam perspektif-islam- dan-kebangsaan, diakses pada 5 Desember 2018, 22.07 WIB. 